Ann. Biol. anim. Bioch. Biophys., 1979, 19 (4 A), 1081-1097.

\title{
Effects of anterior and posterior hypothalamic deafferentation on gonadotrophin and prolactin secretion in ovariectomized ewes under hormonally induced oestrous cycles
}

\author{
par J. C. THIERY, M. BLANC, J. P. RAVAULT *, J. PELLETIER \\ avec la collaboration technique de A. CARATY, C. LAVENET, P. ORGEUR, J. C. POIRIER ef \\ G. VENIER \\ Station de Physiologie de la Reproduction, I.N.R.A., \\ Nouzilly, 37380 Monnaie, France \\ * Faculfé des Sciences de Tours, 37200 Tours, France.
}

Summary. Oestradiol benzoate (OB), when given to ovariectomized ewes under hormonally induced oestrous cycles, caused both negative and positive feedback effects, i. e. decreased FSH levels were followed by an FSH surge 15 to 18 hrs later concomitant with a preovulatory-like $\mathrm{LH}$ release. This injection also caused a prolactin surge with a spiking release pattern between 9 to 18 to 30 to 42 hrs later. Basal FSH levels, as well as those obtained after $O B$ injection, progressively increased from December to April.

Between December and February, no significant variations in prolactin secretion were detected, while later on (February to April) both basal prolactin levels, and those obtained after OB injection rose significantly. These long-term variations of both FSH and prolactin secretion indicate seasonal effects.

After anterior deafferentation of the mediobasal hypothalamus $(\mathrm{MBH}), \mathrm{FSH}$ levels decreased drastically, but remained detectable. The OB-induced surges were totally suppressed in some animals, while in others they showed a very small residual response at the time of the residual LH release. Thus, FSH secretion could be regulated by the same hypothalamic hormone as $\mathrm{LH}$ secretion, i. e. LH-RH. The tonic and/or cyclic regulation was located in the part of the brain anterior to the cut, probably in the septopreoptic-anterior hypothalamic areas.

Residual secretion could be due to the activity of the mediobasal areas, still connected to the pituitary gland and participating in both tonic and cyclic mechanisms.

Posterior deafferentation of the $\mathrm{MBH}$, without effect on $\mathrm{LH}$ and FSH secretion, was performed in January and resulted in an early increase in prolactin levels in February.

Anterior deafferentation of the $\mathrm{MBH}$ caused drastic damping of the $\mathrm{OB}$-induced prolactin response, while the basal level remained unchanged.

It is suggested that the posterior areas of the ewe $\mathrm{MBH}$ may play a role in the regulation of basal prolactin levels and related seasonal changes.

Septopreoptic-anterior hypothalamic areas may have a major part in the control of the $O B-i n d u c e d$ prolactin response. The quantilatively different effects and localizations suggest the existence of at least two separate neural hormones.

In the ewe, oestrogens are reported to induce an FSH discharge during the anoestrus season (Pant et al., 1973 ; Jonas ef al., 1973). 
Increasing oestrogen levels in the blood precede the FSH surge which occurs simultaneously with the preovulatory LH peak (Pant ef al., 1977 ; Bindon et al., 1978), probably via endogenous LH-RH release. Oestrogen is also known to be a potent releaser of prolactin in female sheep (Kann, 1971a) as in female rats (Neil, 1972). However, no data are available concerning $\mathrm{FSH}$ or prolactin in ovariectomized ewes, in which oestradiol triggers both oestrous behaviour and LH surge (Pelletier and Signoret, 1969).

In intact ewes, pituitary stalk section is followed by a continuous, low-level, prolactin secretion (Bryant et al., 1971). This damping of the secretion was attributed both to partial necrosis of the gland and to elimination of a possible prolactin releasing factor (PRF), while continuity of the secretion was ascribed to elimination of a prolactin inhibiting factor (PIF) (Kann and Denamur, 1973). Electrolytic lesions of the hypothalamus in this species support the hypothesis of the existence of two hypothalamic factors. Lesions made in the anterior or posterior part of the mediobasal hypothalamus $(\mathrm{MBH})$ in pregnant or lactating ewes result in reverse effects on prolactin and the development of the mammary gland (Wolinska et al., 1977).

In this species, stimulation of the median eminence (Malven, 1975a), as well as of the preoptic area (Malven, 1975b), both provide evidence for an anterior localization of PRF activity, and suggest a PIF production in the posterior part of the $\mathrm{MBH}$.

In rats and monkeys, the effects of hypothalamic deafferentation on several hormone secretions has been examined (Blake et al., 1973 ; Krey et al., 1975). In the ewe, we showed (Thiery ef al., 1977) that the consequences of hypothalamic deafferentation on the luteinizing hormone (LH) secretion studied by Jackson et al. $(1976,1978)$, could be extended to the control of follicle stimulating hormone (FSH), prolactin secretion and sexual behaviour. However, our first study, carried out in 4 animals did not rule out possible changes due to season or to unspecific surgical trauma.

Accordingly, the present experiments investigated the effects of oestradiol benzoate (OB) on changes in plasma hormone content (gonadotrophins and prolactin) in a comparatively larger number of ovariectomized ewes under artificial oestrous cycles, and their possible long-term variations during successive oestrous cycles. Simultaneously, a study was made of animals with anterior or posterior deafferentation of the mediobasal hypothalamus $(\mathrm{MBH})$ as well as of a sham-operated group of females. Pituitary responsiveness to neurohormones was also tested in all groups in order to confirm that the effects were not due to necrosis of the gland.

\section{Material and methods.}

Animals and experimental groups.

The present results were obtained from the same animals as used in the study of Thiery et al. (1978), where the effects of deafferentation on LH secretion and sexual behaviour were analysed in order to study possible connections in the hypothalamus concerning these two parameters of reproduction.

30 adult lle-de-France ewes, ovariectomized several weeks before the beginning of the study and maintained under artificial oestrous cycles up to that date, were used. The experiment lasted from December 1976 to April 1977. 
The animals were allocated at random to 4 groups according to the type of surgical treatment : 6 intact animals (control group) ; 14 animals undergoing deafferentation anterior to the $\mathrm{MBH}$ (ADA group) ; 5 animals undergoing deafferentation posterior to the $\mathrm{MBH}$ (PDA group) ; 5 sham-operated animals.

Disconnection of the $\mathrm{MBH}$ was made within an area extending from $1 \mathrm{~mm}$ anterior to the anterior clinoid process to $1 \mathrm{~mm}$ posterior to it, i. e. plane 28.5 to 30.5 of the stereotaxic atlas (14 animals, ADA). For the 5 PDA animals, the knife was lowered to the same depth, but $4.5 \mathrm{~mm}$ posterior to plane 29 , i. e. the posterior edge of the $\mathrm{MBH}$.

The sham-operated animals underwent complete preparation including introduction of the knife and contact with the floor of the brain, but the knife was not rotated.

One ADA and one PDA female died within 3 days of surgery. This operation is described elsewhere in detail (Thiery et al., 1978).

Hormonal treatments. - Artificial oestrous cycles were induced in females using an adaptation of Robinson's treatment (1954) - $25 \mathrm{mg}$ of progesterone in olive oil/day for 5 days, $10 \mathrm{mg}$ of progesterone in olive oil on the 6th day followed 48 hrs later by an injection of $50 \mu \mathrm{g}$ of oestradiol benzoate (OB) in olive oil. All injections were intramuscular. The animals underwent three sequences of two successive 14-day artificial cycles, the first sequence before surgery (control cycles-CC, December), the second one 15 to 45 days after the operation (shorf-term cycles-STC, February), and the last one 85 to 115 days after the operation (long-term cycles-LTC, April).

\section{Blood sampling schedule and experimental design.}

In all instances, blood was collected from the jugular vein. In the first cycle of a sequence, blood was sampled at 3-hr intervals from the time of the $O B$ injection up to 42 hrs later. Sampling from 0 to 15 hrs following $O B$ was necessary to gain an understanding of the immediate effects of the steroid. In the second cycle of a sequence, blood was first sampled at the time of $O B$ injection and again from 15 to $42 \mathrm{hrs}$ later.

The pituitary responsiveness to $\mathrm{LH}-\mathrm{RH}$ was tested 37 days after the last $\mathrm{OB}$ injection of the short-term cycles. Animals were bled at successive intervals before and after intravenous injection of $100 \mu \mathrm{g}$ of $\mathrm{LH}-\mathrm{RH}(-60 \mathrm{~min},-45,-30,-15,0,+30$, $+45 \mathrm{~min}$, etc... up to $8 \mathrm{hrs}$ ). The pituitary responsiveness to TRH was tested 37 days after the last $O B$ injection of the second long-term cycle. Animals were bled at successive intervals before and after intravenous injection of $50 \mu \mathrm{g}$ of TRF $(-120 \mathrm{~min}$, $-60,0,+5,+10,+25,+45,+70 \mathrm{~min}$ ).

In this paper, the concentration of FSH and prolactin will be related to the preovulatory-like LH surge, complete data on LH having been described elsewhere (Thiery ef al., 1978).

FSH, LH and prolactin were measured by specific radioimmunoassay (RIA) according to Blanc and Poirier (1979), Pelletier et al. (1968) and Kann (1971), respectively, and expressed as ng HG FSH 225*, CNRS LH M $_{3}$ * or NIH P S 6 per ml of plasma, respectively. RIA antiserum 5 BB and labelled HG FSH 225 were used for FSH. Hor-

* $1 \mathrm{mg} \mathrm{HG} \mathrm{FSH} 225$ is immunologically equivalent to $36 \mathrm{mg} \mathrm{NIH} \mathrm{FSH} \mathrm{S} 3 ; 1 \mathrm{mg}$ CNRS LHM $\mathrm{M}_{3}$ is equivalent to $1.8 \mathrm{mg}$ NIH LH S 1. 
mone (FSH and prolactin) concentration in a sample was computed in line from the $\gamma$ spectrophotometer (LKB Rackgamma 1270) according to a B/Bo*-log dose plot. This program (RIA 0158 B from LKB) included corrections for radioactivity decay.

Histology. - Animals of the anterior, posterior and sham-operated groups were killed at the end of the experiment for histological study of the brain.

The cuts were observed in serial frontal sections of $15 \mu \mathrm{m}$ thickness, which were stained using the Klüver-Barrera technique. These sites were traced on a reconstructed sagital projection adapted from Richard's stereotaxic atlas (1967).

Statistical analysis. - All the mean values presented in this paper were expressed as mean \pm standard error of the mean. The comparison of the effects of deafferentation as well as that of short-term or long-term effects were calculated using the method of factorial analysis of variance. The value of « $P$ » will be given in the text. This method also indicated the effectiveness of the hormonal responses to $O B$ injection, the variations between animals within one group, and the interaction of the operation and the kinetics of the response (Snedecor and Cochran, 1967). Comparisons of two isolated mean values were made using the Wilcoxon test.

\section{Results.}

For both hormones, the initial levels (measured at $O B$ injection time) varied widely between animals (prolactin : from 7 to $283 \mathrm{ng} / \mathrm{ml}$ and $\mathrm{FSH}$ from 15 to $80 \mathrm{ng} / \mathrm{ml}$ ). However, changes in the hormonal values during two successive oestrous cycles in operated groups or during the six successive cycles in the control group (from 15 to $42 \mathrm{hrs}$ after $\mathrm{OB}$ ) were very parallel. Therefore, it is convenient to describe the hormonal changes in kinetic terms with reference to the initial values.

\section{Plasma hormone levels and changes after OB injection in ewes without surgical treatment}

\section{A) FSH.}

These results concern the forty cycles in which the animals were sampled every $3 \mathrm{hrs}$ without interruption from 0 to $42 \mathrm{hrs}$ : each of the 6 control animals during the first cycle of each sequence (i. e. $6 \times 3$ ) and the 22 others (13 ADA, 4 PDA and 5 shamoperated) during one preoperative cycle.

For the first 6-9 hrs following OB injection, stable (10 p. 100 of the cycles), decreasing (48 p. 100) or increasing (42 p. 100) FSH levels were noted (fig. 1). Thus, the mean value calculated at $3 \mathrm{hrs}(30 \pm 3 \mathrm{ng} / \mathrm{ml}$ ) was the same as those calculated at OB injec-

\footnotetext{
* $B=$ amount of labelled hormone bound to antiserum in the presence of unlabelled hormone expressed as cpm/tube.

Bo $=$ amount of labelled hormone bound to antiserum in the absence of unlabelled hormone expressed as cpm/tube.
} 
Control cycles Short lerm cycles Long lerm cycles

ng/ml plasma FSH
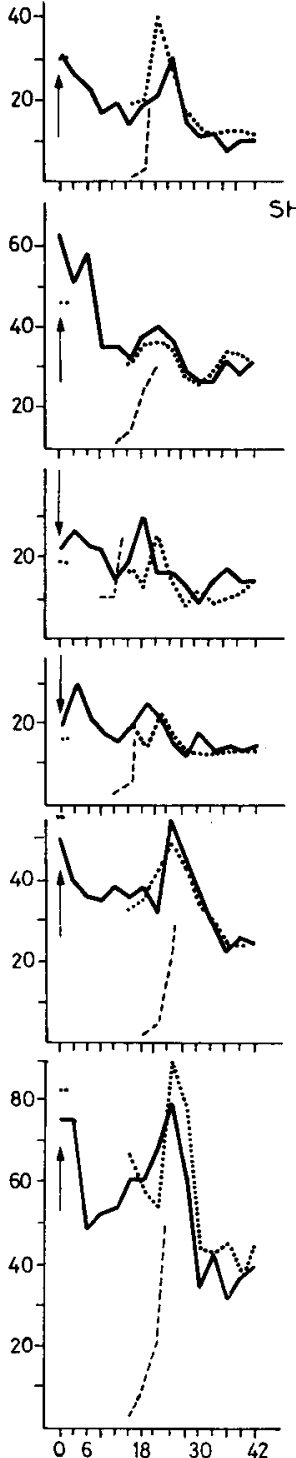

CONTROL EWES
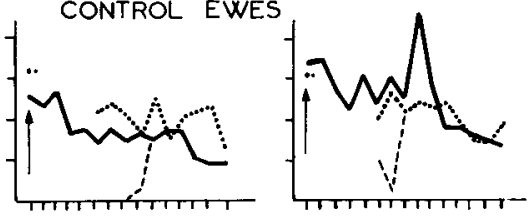

HAM_OPERATED EWES

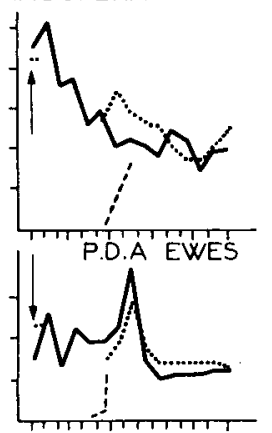

A.D.A EWES
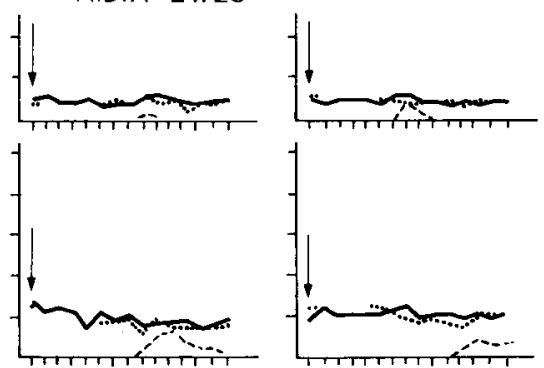

UNILATERAL A.D.A

EWES

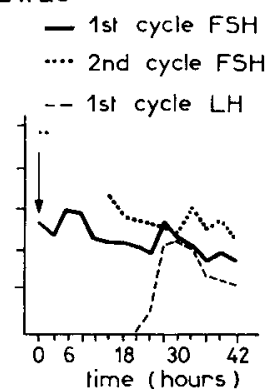

FIG. 1. - Changes in plasma FSH levels after oestradiol benzoate injection ( 0 time) in 1 control, 1 shamoperated, 1 PDA, 2 anterior deafferentated and 1 unilateral anterior deafferentated ewe. The initiation of «pre-ovulatory 》 LH surge is shown to demonstrate the simultaneous rise in FSH levels. Two successive artificial cycles were used in each case. Control cycles : before surgery (December) ; short-term cycles : 15 to 45 days after surgery (February); long-term cycles : 85 to 115 days after surgery (April). Note the LH discharge concomitant with the slight increase in FSH levels in ADA ewes. 
tion time $(30 \pm 3 \mathrm{ng} / \mathrm{ml})$. Later on, from hours $12-15$, plasma FSH was significantly reduced $(23,3 \pm 2.7$ and $21.8 \pm 1.8$ respectively).

Between 15 and $18 \mathrm{hrs}$ plasma FSH began to increase again. Maximum values were not always superior to the intial ones (i. e. time of $O B$ injection). However, this increase was clear, and in all but 1 animal the peak value was systematically higher than the value detected both $6 \mathrm{hrs}$ earlier and $6 \mathrm{hrs}$ after. This FSH release was conco-

Conirol cycles

Short lerm cycles Long lerm cycles

$\mathrm{ng} / \mathrm{ml}$ plasma prolaciin
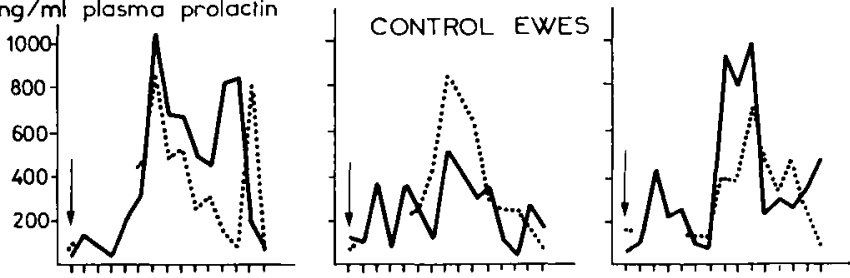

SHAM_OPERATED EWES
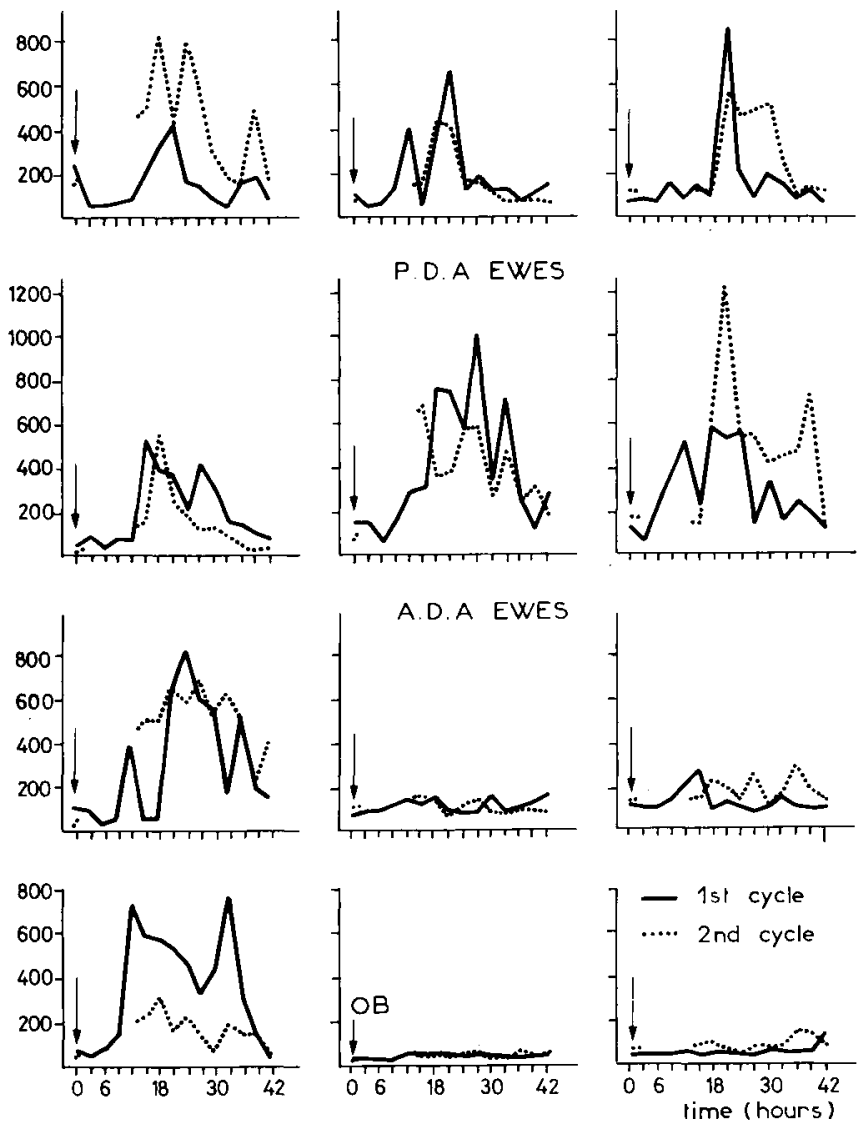

FIG. 2. - Change in plasma prolactin levels after oestradiol benzoate injection (0 time) in 1 control, 1 sham-operated, 1 posferior deafferentated and 2 anterior deafferentated ewes. 
mitant with the preovulatory-like discharge of $\mathrm{LH}$ (see fig. 1) and could be regarded as an OB-induced response. Later on, FSH levels decreased again and fell to a nadir at 35-42 hrs after $\mathrm{OB}$. However, the levels seemed to increase once more after this in 28 out of the 40 cycles.

\section{B) Prolactin.}

For the first 6-9 hrs post-injection, plasma prolactin changes were not consistent, indicating no immediate effect of the steroid (fig. 2). Between 9 and $18 \mathrm{hrs}$ (mean $15.7 \pm 0.5$ ), plasma prolactin increased ; this surge showed a spiking release pattern. Maximum values were obtained between 18 and $30 \mathrm{hrs}$ after $O B$ injection. In some cases (4/40), this maximum value was more than $1000 \mathrm{ng} / \mathrm{ml}$. Later on between 30 and $42 \mathrm{hrs}$, plasma prolactin returned to the initial levels in some animals, but stayed slightly higher in others $(24 / 40)$.

\section{Changes in hormonal secretions from December to April}

\section{A) FSH.}

1. Control group (unoperated). - From December to April, the initial level (measured at the time of $O B$ injection) increased in 5 out of the 6 animals. The mean values $(\mathrm{N}=6)$ were $21.5 \pm 2.3 \mathrm{ng} / \mathrm{ml}$ in CC (December) ; $30.4 \pm 5.8 \mathrm{ng} / \mathrm{ml}$, STC (February); $31.0 \pm 4.1$, LTC (April). Such an increase was also evident during the OB-induced FSH response, as indicated by the profile of the curves (fig. 3). This effect was highly significant : CC vs STC : $\mathrm{P}=1.5 \times 10^{-7}$; STC vs LTC $: \mathrm{P}=2 \times 10^{-5}$.

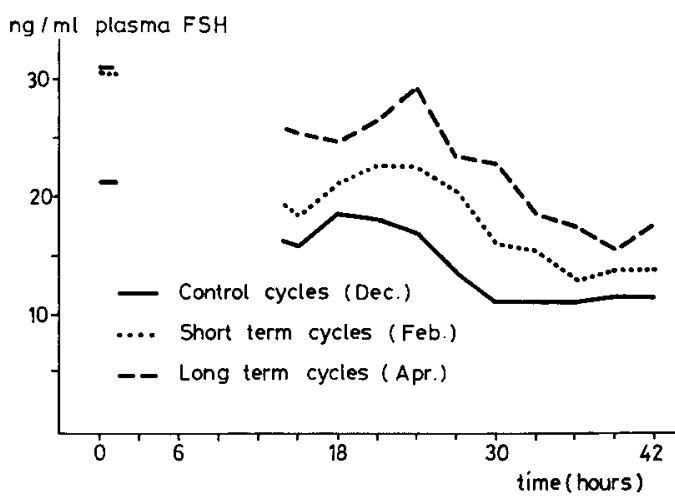

FIG. 3. - Mean FSH levels from December to April in the control group at the time of oestradiol injection and from 15 to 42 hrs later.

2. Sham-operated and PDA groups. - After surgery, in each cycle the animals of both groups underwent changes in plasma FSH levels following OB injection similar to controls.

Furthermore, 3 out of the 5 sham-operated and 3 out of 4 posterior deafferentated animals exhibited statistically significant increases in their FSH secrefion between the 
control cycles (CC, December) and the four subsequent ones (STC, February and LTC, April). Sham-operated group CC vs STC : $\mathrm{P}=1.3 \times 10^{-2}$, PDA group CC vs STC: $P=1.2 \times 10^{-4}$.

3. ADA group. - In 10 animals out of 13 , a bilateral section was seen. Of these 10 animals, 2 had a section at the level of the arcuate nuclei, 3 between the level of the suprachiasmatic and the arcuate nuclei, and 5 passing through the posterior part of the suprachiasmatic nuclei (fig. 4).

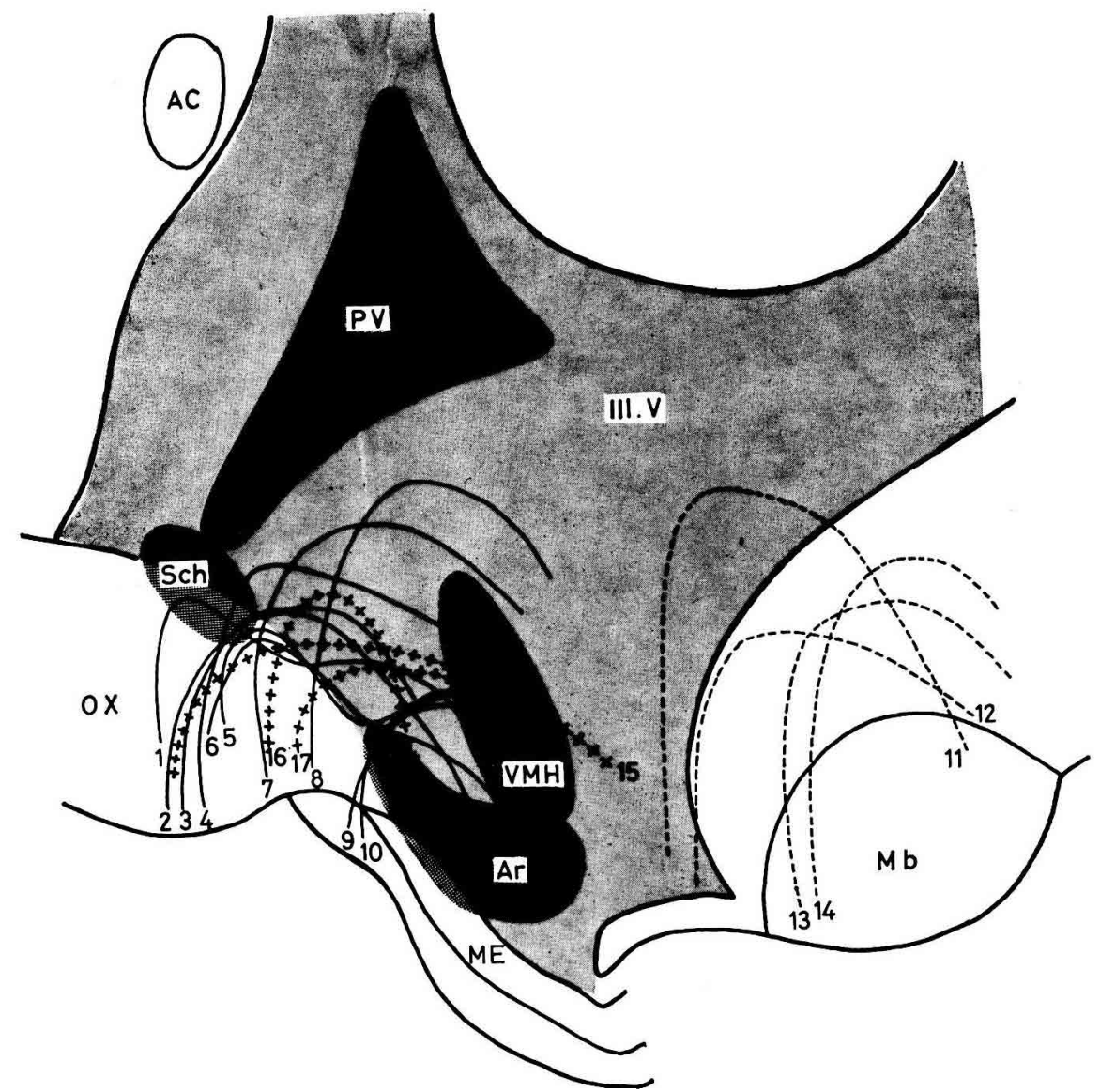

FIG. 4. - Schematic sagittal drawing of the localization of the cuts in 10 anterior bilateral deafferentated ewes (from 1 to 10), 3 unilateral anterior deafferentated ewes (from 15 to 17) and 4 posterior deafferentafed ewes (from 11 to 14). $A C=$ Anterior commissure ; $\mathrm{Ar}=$ Arcuate nucleus ; $\mathrm{ME}=$ Median eminence ; $\mathrm{Mb}=$ Mamillary bodies ; $\mathrm{OX}$ : Optic chiasma ; $\mathrm{PV}=$ Paraventricular nucleus ; $\mathrm{Sch}=$ Suprachiasmatic nucleus $; \mathrm{VMH}=$ Ventromedial nucleus ; III $\mathrm{V}=$ Third ventricule.

In these 10 females, the initial FSH levels fell dramatically (mean : $29.6 \pm 5.1 \mathrm{ng} / \mathrm{ml}$ before surgery vs $6.1 \pm 0.6$ after surgery).

Within this ADA group no significant variations could be found with respect to the antero-posterior location of the cut. For this reason, the 10 ADA bilateral females can 
be regarded as an homogeneous experimental group. No statistically significant differences could be detected between ST and LT cycles $(p=0.09)$. Therefore, the results are listed without special reference to short or long-term cycles.

No FSH release could be detected (fig. 1) following OB treatment. However, 6 animals showed a very slight increase in FSH levels at the time when, before surgery, a peak has been normally observed. This slight increase in $\mathrm{FSH}$ value occurred at the time of the residual $\mathrm{LH}$ surge detected in the same animals.

In 3 of the 13 animals, the deafferentation was predominantly or exclusively unilateral : in one (ewe no. 17), the section was localized at the arcuate level and included a part of the median eminence; in another (ewe no. 15), the section was posterior to the suprachiasmatic nucleus but a lesion appeared at the level of median eminence. Both females showed damping of the initial basal level and suppression of the OB-induced FSH release. In the 3 rd one, the section was located in the posterior part of the suprachiasmatic nucleus (ewe no. 16). The damping of the FSH level was slight (about 60 p. 100) and the OB-induced response remained detectable, appearing at the time of the small LH surge (fig. 1).

B) Prolactin.

1. Control group. - From December (CC) to February (STC), no statistically significant changes were detected in either basal levels : $67.5 \pm 21.5 \mathrm{ng} / \mathrm{ml}$ (December) versus $65.4 \pm 10.8 \mathrm{ng} / \mathrm{ml}$ (January), or $O B$-induced response $(P=0.101)$. From February to April, the initial level $(152 \pm 41 \mathrm{ng} / \mathrm{ml})$, as well as the OB-evoked release (fig. 5), increased significantly as compared to both short-term cycles $\left(P=3.5 \times 10^{-2}\right)$ and control cycles $\left(P=8 \times 10^{-4}\right)$.

2. Sham-operated groups. - Following surgery, a slight decrease in the OBinduced prolactin response appeared in 3 out of 5 animals during the first STC and was still present in the second STC in 2 out of these 3 females. The decrease between the two control cycles and the two STC ones was statistically significant $\left(P=3 \times 10^{-3}\right)$. In LTC cycles the level of the response was recovered and reached a higher value than in the control ones.

3. PDA group. - The 4 animals showed bilateral sections localized from the anterior part of the mamillary bodies to the posterior part of the mediobasal hypothalamus (fig. 4). No special changes in prolactin secretion, within this group of 4 females, were associated with a particular antero-posterior localization of the cut.

Following deafferentation, the initial level of prolactin (measured at $O B$ injection time) increased from $34 \pm 7 \mathrm{ng} / \mathrm{ml}$ (December) to $101 \pm 21 \mathrm{ng} / \mathrm{ml}$ (February) (fig. 5). Furthermore, the mean values following $O B$ injection also increased drastically $\left(P=2 \times 10^{-8}\right)$ (fig. 2 and 5$)$. Factorial analysis of variance indicated no effect of the surgical operation on the profile of the curve $(P=0.72)$. During LTC (April) no more significant increase could be detected as compared to the previous STC. The basal value was : $121 \pm 34 \mathrm{ng} / \mathrm{ml}$, while the LTC responses were not significantly different from the STC response $(P=0.9)$.

4. $A D A$ group. - The initial level of prolactin measured at $O B$ injection time during STC was not affected in 8 out of the 10 bilateral ADA ewes, while it decreased to 
CONTROL EWES

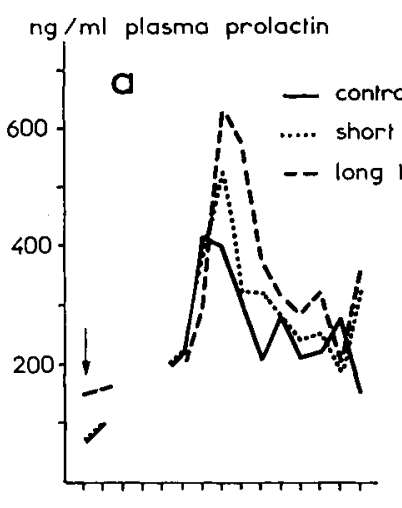

$\mathrm{ng} / \mathrm{ml}$ prolactin

e

P.D.A EWES

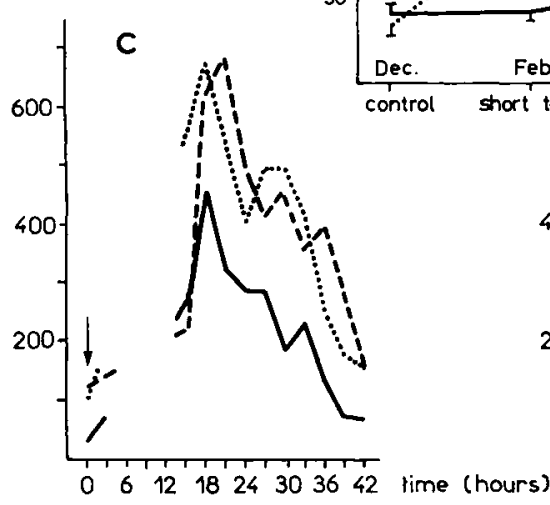

SHAM_OPERATED EWES

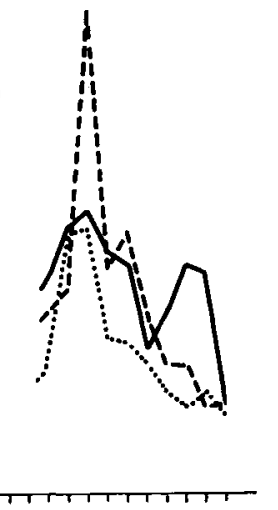

- Control ewes

- - Sham_operated

- ADA ewes .... PDA

FIG. 5. - a) b) c) d) Time course of the mean prolactin response after oestradiol benzoate injection ( 0 time) in the $\mathbf{4}$ groups from December to April. e (middle) : Changes in the mean prolactin basal level in these groups.

41 and 44 p. 100 of the preoperative values in the remaining 2 females. Later on during LTC, these 2 animals (ewe no. 4 and ewe no. 9) recovered and the levels were similar to these of the preoperative cycles.

For these 10 animals, the mean basal levels measured at $O B$ injection time were, respectively : $C C=38 \pm 7 \mathrm{ng} / \mathrm{ml} ; S T C=43 \pm 5 \mathrm{ng} / \mathrm{ml}$ and $\mathrm{LTC}=64 \pm 8 \mathrm{ng} / \mathrm{ml}$. Thus, in a limited way the mean basal level increased slightly from STC to LTC, as compared to the control group. This increase was statistically significant : $P<0.03$ (Wilcoxon test).

In contrast with the basal level, the OB-induced prolactin response during STC was drastically damped in all the 10 females (fig. 2). This effect was not quantitatively 
related to the anteroposterior localization of the cut within the ADA group. During LTC, a slight, although significant, increase of the hormone level was detected $\left(P=5 \times 10^{-5}\right)$, but these levels remained drastically damped as compared to those of the control group (fig. 5). The 3 unilaterally deafferentated animals showed effects comparable to the bilaterally deafferentated ones.

\section{Pituitary responsiveness to neurohormone injection}

1. Control group. - Plasma FSH levels increased slightly in all but 1 animal after the injection of $100 \mu \mathrm{g}$ of LH-RH. Due to variations in the four values preceding the injection, the maximum post-injection values ranged from 97 to 144 p. 100 (mean $124 \pm 7.6$ p. 100) of the highest preinjection levels (fig. 6).

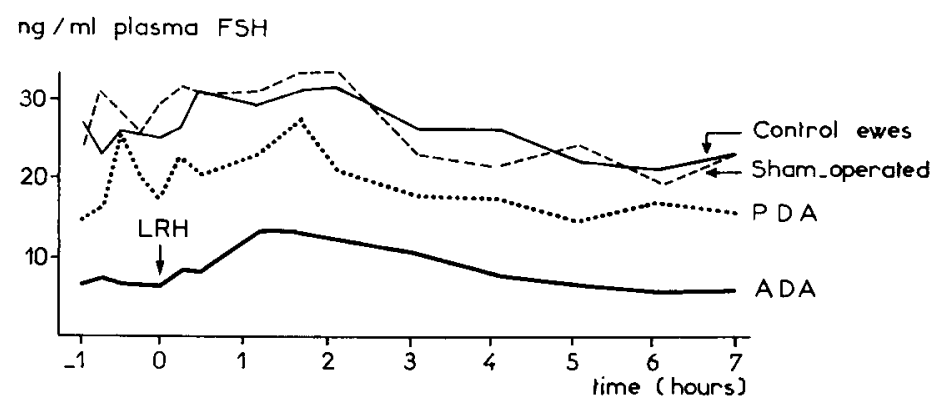

FIG. 6. - Time course of the mean FSH response after $100 \mu \mathrm{g} \mathrm{LH}-\mathrm{RH}$ injection (0 time) in the 4 groups of animals.

The level of prolactin in the blood increased after the injection of TRH and reached a maximum of 644 to more than $2000 \mathrm{ng} / \mathrm{ml}$; (mean $=1296 \pm 236 \mathrm{ng} / \mathrm{ml})$.

2. Sham-operated and PDA groups. - FSH responses to LH-RH were the same as in control animals. In the 5 sham-operated animals, the maximum values ranged from 107 to 138 p. 100 (mean $128 \pm 5.41$ p. 100) of the highest preinjection ones, and in the 4 PDA, the responses ranged from 77 to 139 p. 100 (mean $115 \pm 11.03$ p. 100).

Prolactin responses to TRH were not different from those of the control group. The levels of prolactin in sham-operated animals reached values ranging from 539 to $1241 \mathrm{ng} / \mathrm{ml}$ (mean : $897 \pm 111 \mathrm{ng} / \mathrm{ml}$ ) ; they varied from 349 to more than $2000 \mathrm{ng} / \mathrm{ml}$ (mean : $986 \pm 356 \mathrm{ng} / \mathrm{ml}$ ) in the PDA group.

3. ADA group. - The FSH response to $\mathrm{LH}-\mathrm{RH}$ was observed in all the 10 animals (fig. 6). These responses appeared to be clearer than in the control, sham-operated and PDA groups, despite (or due to) the lower mean value of the hormone level. The maximum post-injection values ranged from 118 to 370 p. $100(214 \pm 23$ p. 100) of the preinjection ones. The 3 unilaterally deafferentated ewes showed similar responses : 139 p. 100 (ewe no. 15), 207 p. 100 (ewe no. 16), and 189 p. 100 (ewe no. 17).

Prolactin responses to TRH were not different from the control ones, and the 
maximum values ranged from 686 to more than $2000 \mathrm{ng} / \mathrm{ml}$ (mean $1086 \pm 175$ $\mathrm{ng} / \mathrm{ml}$ ); ewe no. 10 exhibited a lower maximum (192 ng/ml).

The 3 unilaterally deafferentated ewes showed normal responses : ewe no. 15 : $534 \mathrm{ng} / \mathrm{ml}$; ewe no. $16: 1788 \mathrm{ng} / \mathrm{ml}$; ewe no. $17: 937 \mathrm{ng} / \mathrm{ml}$.

\section{Discussion.}

The results obtained in animals without surgical treatment show that FSH basal levels can vary from one ovariectomized animal to another. The differences persisted throughout the whole study, indicating that they are effectively individual ones. This is in good agreement with the results of Findlay and Cumming (1976), who found that the major source of variation of FSH levels in intact females (75 p. 100) was attributable to the animals.

Results from control cycles show that $\mathrm{OB}$ is able to induce both an FSH decrease and later on, an FSH release (concomitant with the $\mathrm{LH}$ peak) in ovariectomized ewes, as it does in anoestrus females (Pant ef al., 1973 ; Jonas et al., 1973). This suggests that the nervous control in these situations may be similar for both $\mathrm{LH}$ and FSH regulation. The small amplitude of the 15 to $18 \mathrm{hr}$ FSH release, as compared with the initial level in spayed females, may be surprising at first sight. In cycling ewes, plasma FSH decreased 3 days before oestrus (Pant et al., 1977 ; Cahill, 1979), thus resetting the basal level and explaining the shape of the FSH preovulatory surge. In ovariectomized ewes, the increased tonic release of the hormone can mask, to some extent, the response to endogenous LH-RH. The same phenomenon could explain why mediobasal deafferentation, which drastically damped hypothalamic stimulation, made the response to the exogenous releasing hormone more evident in ADA group than in controls. The nonimmediate decrease in FSH levels observed after OB injection and also noted by Jonas ef al. (1973), indicates, as proposed by Cumming ef al. (1976), that this negative feedback is a slower acting process than for $\mathrm{LH}$ secretion.

The results obtained from the same cycles in ovariectomized ewes show prolactin changes very similar to the ones observed in intact ewes during normal oestrus (Kann, 1971), with a spiking pattern of secretion appearing just before LH surge or simultaneously with it ; thus, these changes can be considered as OB-induced responses. Large individual variations exist, which have also been reported in pregnant females (Kann and Denamur, 1974) and in spayed ewes (Malven, 1975).

In the "lle-de-France » breed of sheep, the breeding season extends from July to December (Thimonier and Mauleon, 1969), with the decrease in sexual activity starting in January. Thus, the 120 to 200 p. 100 increase in the FSH levels, found between December and the following month, as well as the changes observed in prolactin secretion, could be possibly related to seasonal changes. In ram, parallel seasonal changes were found in FSH (Sanford et al., 1978 ; Blanc and Courot, unpublished), and prolactin secretions (Ravault, 1976). Thus, spayed ewes seemed to respond to the photoperiod like males in this experimental situation.

Following deafferentation, the pituitary responsiveness to neurohormones is very clear in all the groups. The sham-operated group showed FSH changes similar to those of the control group and the prolactin response was only temporarily affected. Thus, 
the observed effects could be regarded as resulting from changes in brain regulation, but not from surgical trauma at the pituitary level following deafferentation.

In anterior deafferentated animals, the damping of the initial FSH levels following surgery indicates that tonic release of the hormone is at least partly under hypothalamic control, as in rat (Kalra, 1976). Following OB injection, the increased levels which are concomitant with the residual LH surge, though still detectable in some animals, are also drastically damped, thus implying the role of neurosecretion in this response. These data do not allow the elimination of a specific FSH releasing factor, but no evidence of this was found.

Data from this publication, as those of a previous one (Thiery et al., 1978), strongly suggest that the neural stimulation of both $\mathrm{LH}$ and FSH involved the same releasing hormone (i. e. LH-RH) since the basal levels, preovulatory-like release in control ewes, and residual secretions in ADA animals always underwent a similar cycle of changes.

Furthermore, no dissociation of «tonic » and «cyclic» release could be made with regard to the position (more or less anterior) of the cut in the ADA group. Therefore, if would appear that in sheep, the regulation of tonic and cyclic gonadotrophin secretion is not located in independent nervous areas, or at least that it is mediated by the same neurosecrefory final common pathway. Such an hypothesis was proposed for female rats by Kalro (1976) who suggested that preoptic LH-RH may be involved in the tonic as well as the cyclic discharge of LH from the pituitary.

In one male sheep, Hoffman et al. (1978) showed LH-RH-producing cells to be present both in septopreoptic anterior hypothalamic areas and in the mediobasal hypothalamus. Thus, the residual tonic and cyclic secretions of gonadotrophins in our experiments could be possibly due to a few MBH-LH-RH cells posterior to the cut. Similar results were obtained by Kalra ef al. (1977) in deafferentated male rats, where the residual population of $\mathrm{MBH}-\mathrm{LH}-\mathrm{RH}$ cells were shown to respond to steroids. The alternative is that the residual secretions could be due to a few lateral or dorsal inputs coming from anterior areas which were not damaged by the knife. However the constancy of the effects in the ADA group, regardless of the lateral extension of the cut, does not seem to support this hypothesis.

Posterior deafferentation resulted in a significant early increase in the prolactin basal level in February, while the relative amplitude (from basal to maximum values) of the OB-induced response remained unaffected. Such an effect was not observed in sham-operated animals, and therefore cannot be interpreted as postoperative stress.

This suggests an inhibiting role either of structures destroyed by the cut (lesion effect) or of inputs coming from more posterior structures. Such an inhibiting role of these areas has also been suggested by Domanski and Polkowska (1973) and to some extent by Malven (1975). Both suggested a possible release of PIF from these areas.

The level of prolactin found for the PDA group in February within the limits of physiological change, is similar to the one normally found in April. Thus it would appear that posterior deafferentation resulted in an experimental advance of the normal seasonal variation.

In contrast with LH and FSH secretion (Jackson ef al., 1978 ; Thiery ef al., 1978), the anterior section only damps the OB-induced prolactin response, leaving the basal level unchanged in February. In addition, it diminished the seasonal increase in the basal level normally detected in April. This suggests a stimulatory role of the anterior 
hypothalamus-preoptic area in prolactin secretion in the sheep. This is in agreement with the results of Malven (1975b), who found a release of prolactin in ewes following stimulation of the preoptic areas, and also with the results from Wolinska et al. (1977), who showed disturbances of lactation and a decrease in prolactin levels following lesions of these areas in lactating ewes. Quadri et al. (1977) reported a similar effect attributable to this part of the hypothalamus in the rhesus monkey.

The slight but significant increase in prolactin secretion observed in the ADA group between short-term and long-term cycles could be due at first sight to post-operatory

\begin{tabular}{|c|c|c|c|}
\hline & $\begin{array}{l}\text { CONTROL } \\
6 \text { ovariectomized } \\
\text { ewes }\end{array}$ & $\begin{array}{l}\text { A.DA EWES } \\
13 \text { ovariectomized } \\
\text { ewes anteriorly } \\
\text { dectferentated } \\
\text { between December } \\
\text { and February }\end{array}$ & $\begin{array}{l}\text { P.D.A EWES } \\
4 \text { ovariectomized } \\
\text { ewes posteriorly } \\
\text { decfferentated } \\
\text { between December } \\
\text { and February }\end{array}$ \\
\hline $\begin{array}{l}\mathrm{L} \\
\mathrm{H}\end{array}$ & 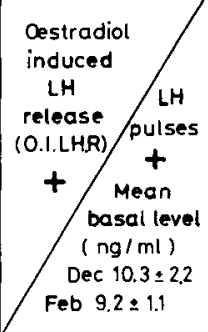 & 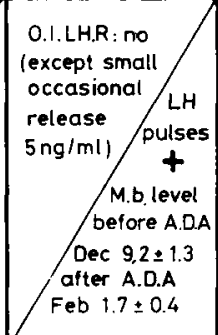 & $\begin{array}{c}\text { O.I.LH.R } \\
+\int_{\text {pulses }}^{\text {LH }}+ \\
\text { M.D. level } \\
\text { before P.D.A } \\
\text { Dec 11.5 } \pm 2.1 \\
\text { after P. D.A } \\
\text { Feb B.8 } \pm 1.8\end{array}$ \\
\hline $\begin{array}{l}F \\
S \\
H\end{array}$ & $\begin{array}{l}\text { Destradiol } \\
\text { induced } \\
\text { FSH } \\
\text { release } \\
\text { (O.I.FSH.R) } \\
+/ \text { Mean } \\
\text { basal level } \\
(\mathrm{ng} / \mathrm{ml}) \\
\text { Dec } 21.5 \pm 2.3 \\
\text { Feb } 30.4 \pm 5.8\end{array}$ & $\begin{array}{l}\text { O.I.FSH.R: no } \\
\text { or small } \\
\text { residual } \\
\text { release } \\
\text { M.b. level } \\
\text { before A.D.A } \\
\text { Dec } 29.5 \pm 5.1 \\
\text { after A.D.A } \\
\text { Feb } 6.1 \pm 0.6\end{array}$ & $\begin{array}{l}\text { O.I.FSH.R } \\
+ \\
\text { M.b. level } \\
\text { before P.D.A } \\
\text { Dec 21.8: } 4.0 \\
\text { after P. D.A } \\
\text { Feb } 18.0=3.6\end{array}$ \\
\hline $\begin{array}{l}P \\
R \\
0 \\
L \\
A \\
C \\
T \\
1 \\
N\end{array}$ & $\begin{array}{c}\text { Oestradiol } \\
\text { induced } \\
\text { Prolactin } \\
\text { release } \\
\text { (O.1PR.R) } \\
+ \text { Mean } \\
+ \text { basal leve } \\
(n g / m 1) \\
\text { Dec } 67.5 \pm 21.5 \\
\text { Feb } 65.4=10.8 \\
\text { Apr } 152.0 \pm 41.0\end{array}$ & $\begin{array}{l}\text { O.I.PR.R } \\
\text { no } \\
\text { M.b.level } \\
\text { before A.DA } \\
\text { Dec 38.0.7.0 } \\
\text { after A.D.A } \\
\text { Feb } 43.0 \pm 5.0 \\
\text { Apr } 64.0 \pm 8.0\end{array}$ & $\begin{array}{l}\text { O.I.PR.R } \\
+ \\
\text { M.b.leve } \\
\text { DeforeP.DA } 34.0 \div 7.0 \\
\text { ofter P.D.A } \\
\text { Feb } 101.0 \pm 21.0 \\
\text { Apr } 121.0 \pm 34.0\end{array}$ \\
\hline $\begin{array}{l}\text { FEMALE } \\
\text { RECEPTIV! } \\
\text { following } \\
0 . B \text { injecti } \\
\text { ( Feb. and }\end{array}$ & $\begin{array}{ll} & + \\
\text { ApY } & \\
\text { Apr.) } & 6 q\end{array}$ & $\begin{array}{l}+8 q \\
-5 q\end{array}$ & $\begin{array}{c}+ \\
4 q\end{array}$ \\
\hline
\end{tabular}


recovery. However, it occurs at the same time as the seasonal rise observed in control animals, while there is no significant recovery in $\mathrm{LH}$ and FSH secretions in the same ADA animals. Thus, the changes found in the ADA group in the present experiments, as well as the decrease in basal prolactin levels detected in a preliminary experiment carried out between July and December (Thiery et al., 1977), could be attributed to photoperiod-induced modifications. It is not yet known whether this change is due to residual excitatory inputs not severed by the anterior cut and acting via an unknown PRF produced anteriorly, or whether it is a result of inhibition of PIF release originating in the posterior hypothalamus, this area being undammaged by anterior deafferentation.

Thus, in the ewe, the OB-induced prolactin response appears to be regulated by anterior hypothalamic inputs, while basal secretion could be controlled by both posterior and/or anterior inputs. The quantitatively different effects of PDA and $A D A$, respectively, suggest that these regulations could imply several neurohormone secretions of unknown biochemical structure (peptidergic, aminergic or other).

The effects of anterior and posterior deafferentation in the ewe presented in a previous paper (Thiery et al., 1978) and in the present one are summarized in the table.

Reçu en octobre 1978.

Accepté en mars 1979.

Acknowledgments. - The authors wish to acknowledge the helpful assistance of $B$. Chominat and J. L. Dacheux for computer analysis of the results and Mme H. Williams for preparing the English translation of the manuscript. The authors are also grateful to Dr. Herber Grimek (University of Wisconsin, Madison, USA) for his generous gift of a highly purified ovine FSH preparation (HG FSH 225). The work was supported by «ATP » I. N. S. E. R. M. 46-77-78 Contrat no 7 « Hormones neuropeptides et réactions comportementales normales et pathologiques ».

Résumé. Chez la brebis ovariectomisée et entretenue en cycles œstriens artificiels, l'injection de benzoate d'œstradiol (BO) entraîne une rétroaction négative (diminution du niveau de FSH plasmatique) suivie de 15 à $18 \mathrm{~h}$ plus tard d'une décharge de l'hormone concomitante du pic de type « préovulatoire » de LH. Cette injection entraîne également une décharge de prolactine polyphasique de 9-18 à 30-42 h après l'injection.

Entre les mois de décembre et avril, le niveau de base de FSH comme la réponse à l'injection d'œstrogène augmentent progressivement. Les niveaux de sécrétion de prolactine restent stables de décembre à février mais s'élèvent ensuite en avril. Ces variations des hormones considérées pourraient représenter une évolution saisonnière.

Après la déafférentation antérieure de l'hypothalamus médiobasal (pratiquée en janvier), les niveaux plasmatiques de FSH diminuent considérablement mais l'hormone reste détectable. La décharge de FSH consécutive à l'injection de $\mathrm{BO}$ est supprimée totalement chez certains animaux. D'autres présentent une augmentation de niveau de petite amplitude au moment du pic résiduel de LH. Ceci suggère que les sécrétions de LH et FSH puissent être sous l'influence du même facteur hypothalamique de décharge.

Le contrôle des sécrétions gonadotropes toniques et cycliques pourrait être dû aux mêmes zones antérieures aux déafférentations (régions septopréoptiques et hypothalamiques antérieures). Les sécrétions résiduelles pourraient dépendre de l'activité des aires médiobasales qui participeraient partiellement aux deux mêmes fonctions.

La déafférentation postérieure de l'hypothalamus médiobasal (MBH) pratiquée en 
janvier (sans effet sur les sécrétions de $\mathrm{LH}$ ef $\mathrm{FSH}$ ) entraîne $u$.le augmentation significative du niveau de prolactine dès le mois de février.

La déafférentation antérieure abolit la décharge de prolactine résultant de l'injection de $B O$ sans modifier le niveau de sécrétion basal.

II semble que les zones postérieures de $\mathrm{MBH}$ puissent jouer un rôle dans la régulation de sécrétion basale de prolactine, notamment dans ses variations saisonnières. Les régions septopréoptiques et hypothalamiques antérieures joueraient un rôle dans la sécrétion basale comme dans la décharge induite par l'injection de $\mathrm{BO}$.

La différence quantitative des effets mesurés et des localisations suggère l'existence d'au moins deux facteurs nerveux régulant la sécrétion de prolactine chez la brebis.

\section{References}

BINDON B. M., BLANC M. R., PELLETIER J., TERQUI M., THIMONIER J., 1978. Periovulatory gonadotrophin and ovarian steroid patterns in sheep of breeds with differing fecundity. $J$. Reprod. Fert. (in press).

BLAKE C. A., SCARAMUZZI R. J., NORMAN R. L., HILLIARD J., SAWYER C. H., 1973. Effects of hypothalamic deafferentation on circulating levels of $\mathrm{LH}, \mathrm{FSH}$, prolactin and testosterone in the male rat. Endocrinology, 92, 1419-1425.

BLANC M. R., POIRIER J. C., 1979. A new homologous radioimmunoassay for ovine follicle stimulating hormone: development and characterization. Ann. Biol. anim. Bioch. Biophys., 19, 1011-1026.

BRYANT G. D., GREENWOOD F. C., KANN G., MARTINET J., DENAMUR R., 1971. Plasma prolactin in the oestrous cycle of the ewe : effects of pituitary stalk section. J. Endocr., 51, 405-406.

CAHILL L. P., 1979. Studies of folliculogenesis in the sheep. Thèse d'Etat, Univ. Paris VI.

CUMMING I. A., BAXTER R. W., BUCKMASTER J. B., JONAS H. A., FINDLAY J. K., GODING J. R., 1976. Control of FSH secretion in the ewe. J. Reprod. Fert., 36, 447-448.

DOMANSKI E., POLKOWSKA J., 1973. The hypothalamic areas involved in the control of mammotrophic and lactotrophic processes in sheep. Endocr. Exp., 7, 229-246.

FINDLAY J. K., CUMMING I. A., 1976. FSH in the ewe : effects of season, live weight and plane of nutrition on plasma FSH and ovulation rate. Biol. Reprod., 15, 335-342.

HOFFMAN G. E., MELNYK V., HAYES T., BENNETT-CLARKE C., FOWLER E., 1978. Immunocytology of LH-RH neurons, 66-82. In SCOTT D. E., KOZLOWSKI G. P., WEIDL A., Brain endocrine inferaction, III. Karger, Basel.

JACKSON G. L., KUEHL D., ZALESKI A., 1976. Effects of anterior hypothalamic deafferentation on LH secretion in the ewe 9th ann. Meet. Soc. Study of Reprod. Univ. of Pens., Abstr. no 27.

JACKSON G. L., KUEHL D., MCDOWELL K., ZALESKI A., 1978. Effects of hypothalamic deafferentation on secretion of luteinizing hormone in the ewe. Biol. Reprod., 18, 808-819.

JONAS H. A., SALAMONSEN L. A., BURGER H. G., CHAMLEY W. A., CUMMING I. A., FINDLAY J. K., GODING R. J., 1973. Release of FSH after administration of gonadotrophin-releasing hormone or estradiol to the anoestrus ewe. Endocrinology, 92, 862-865.

KALRA S. P., 1976. Tissue levels of luteinizing Hormone-Releasing hormone in preoptic area and hypothalamus, and serum concentrations of gonadotrophins following anterior hypothalamic deafferentation and estrogen treatment of the female rat. Endocrinology, 99, 101-107.

KALRA S. P., KALRA P. S., O'MICHELL E., 1977. Differential response of luteinizing HormoneReleasing hormone in the basal hypothalamus and the preoptic area following anterior hypothalamic daefferentation and/or castration in the male rats. Endocrinology, 100, 201-203.

KANN G., 1971a. Variations des concentrations plasmatiques de l'hormone lutéinisante ef de la prolactine au cours du cycle œestrien de la brebis. C. R. Acad. Sci. Paris, sér. D, 272, 2934-2937.

KANN G., 1971b. Dosage radioimmunologique de la prolactine plasmatique chez les ovins. $C$. $R$. Acod. Sci. Paris, sér. D, 272, 2808-2811.

KANN G., DENAMUR R., 1973. Changes in plasma levels of prolactin and LH induced by luteolytic or luteotrophic treatment in intact cycling sheep after section of the pituitary stalk. Acta endocr., 73, 625-634.

KANN G., DENAMUR R., 1974. Possible role of prolactin during the oestrous cycle and gestation in the ewe. J. Reprod. Fert., 39, 473-483. 
KLUVER H., BARRERA E., 1953. A method for the combined staining of cells and fibers in the central nervous system. J. Neuropathol. exp. Neurol., 12, 400-403.

KREY L. C., BUTLER W. R., KNOBIL E., 1975. Surgical disconnection of the medial basal hypothalamus and pituitary function in the rhesus monkey. I. Gonadotropin secretion. Endocrinology, 90, 1073-1087.

MALVEN P. V., 1975a. Immediate release of prolactin and biphasic effects on growth hormone release following electrical stimulation of the median eminence. Endocrinology, 97, 808-815.

MALVEN P. V., 1975b. Prolactin release induced by electrical stimulation of the hypothalamic preoptic area in unanesthetized sheep. Neuroendocrinology, 18, 65-71.

NEIL J. D., FREEMAN M. E., TILLSON S. A., 1971. Control of the proestrus surge of prolactin and luteinizing hormone secretion by estrogens in the rat. Endocrinology, 89, 1448.

PANT H. C., FITZPATRICK R. J., HOPKINSON C., 1973. Interrelationship between plasma follicle stimulating hormone (FSH) and $17 \beta$ oestradiol in sheep during the oestrous cycle. Acfo endocr. suppl. 177, 12.

PANT H. C., HOPKINSON C. R. N., FITZPATRICK R. J., 1977. Concentration of oestradiol, progesterone, luteinizing hormone and follicle stimulating hormone in the jugular venous plasma of ewes during the oestrous cycle. J. Endocr., 73, 247-255.

PELLETIER J., KANN G., DOLAIS J., ROSSELIN G., 1968. Dosage radioimmunologique de I'hormone lutéinisante plasmatique chez le mouton. Mise au point de la technique de dosage. C. $R$. Acad. Sci. Paris, sér. D, 266 2291-2294.

PELLETIER J., SIGNORET J. P., 1969. Contrôle de la décharge de LH dans le sang par la progestérone ef le benzoate d'œstradiol chez la brebis castrée. C. R. Acad. Sci. Paris, sér. D, 269, 2595-2598.

QUADRI K. S., NORMAN R. L., SPIES H. G., 1977. Prolactin release following electrical stimulation of the brain in ovariectomized and ovariectomized estrogen-treated Rhesus monkeys. Endocrinology, 100, 325-330.

RAVAULT J. P., 1976. Prolactin in the ram : seasonal variations in the concentration of blood plasma from birth until three years old. Acta endocr., 83, 720-725.

RICHARD P., 1967. Allas stéréotaxique du cerveau de brebis éd. INRA (Paris).

ROBINSON T. J., 1954. Relationships of oestrogen and progesterone in oestrous behaviour of the ewe. Nature, 173, 878.

SANFORD L. M., BEATON D. B., HOWLAND B. E., PALMER W. M., 1978. Photoperiod-induced changes in LH, FSH, prolactin and testosterone secretion in the ram. Can. J. Anim. Sci., 58, 123128.

SNEDECOR G. W., COCHRAN W. G., 1967. Stotistical methods. lowa State Univ. Press (III. USA). THIERY J. C., SIGNORET J. P., BLANC M. R., PELLETIER J., RAVAULT J, P., CARATY A., LAVENET C., ORGEUR P., POIRIER J. C., VENIER G., 1977. Effects of anterior hypothalamic deafferentation on LH, FSH, prolactin and sexual behaviour in the ovariectomized ewe. IRCS Med. Sci., 5, 434.

THIERY J. C., PELLETIER J., SIGNORET J. P., 1978. Effect of hypothalamic deafferentation on LH and sexual behaviour in ovariectomized ewe under hormonally induced oestrous cycle. Ann. Biol. anim. Bioch. Biophys., 18, 1413-1426.

THIMONIER J., MAULEON P., 1969. Variations saisonnières du comportement d'œstrus et des activités ovarienne et hypophysaire chez les ovins. Ann. Biol. anim. Bioch. Biophys., 9, 233-250.

THIMONIER J., RAVAULT J. P., ORTAVANT R., 1978. Plasma prolactin variations and cyclic ovarian activity in ewes submitted to different light regimens. Ann. Biol. onim. Bioch. Biophys., 18, 12291235.

WOLINSKA E., POLKOWSKA J., DOMANSKI F., 1977. The hypothalamic centers involved in the control production and release of prolactin in sheep. J. Endocr., 73, 21-29. 